W kilku kolejnych referatach dokonano przeglądu źródeł cyfrowych, i tak Beata Przewoźnik (IBIN UŚ) omówiła Górskie fora, blogi i serwisy społecznościowe jako formę wymiany informacji $i$ komunikacji górskiej w Internecie (prywatne strony „ludzi gór”); Radosław Piątek (student kierunku Informacja w e-społeczeństwie na UMCS w Lublinie) E-motoryzacje - zasoby informacyjne polskiego Internetu dotyczace motoryzacji (na wybranych przyktadach) (witryny producenckie, portale, fora dyskusyjne, blogi); a Wanda Ciszewska (IINiB UMK) Serwisy dziennikarstwa obywatelskiego - przejaw demokratyzacji życia czy ciekawości świata? (Wiadomości24.pl, Interia360.pl, Kontakt24).

Z zaprezentowanych $w$ Lublinie referatów wyłonił się obraz przede wszystkim praktycznych zastosowań technologii i narzędzi sieciowych w wielu aspektach - naukowych, bibliotekarskich i edukacyjnych. Podczas konferencji podkreślano wielokrotnie szybkość ewolucji zachodzącej w środowisku sieciowym, która bezpośrednio wpływa na jakość życia we współczesnym świecie - wzbogacając je atrakcyjnymi formami komunikacji pracowników naukowych, wychowawców, bibliotekarzy i innych użytkowników tego medium. Rola instrumentów internetowych, zwłaszcza tych osiągalnych bez żadnych ograniczeń i barier, zatem stale rośnie. Komunikacja internetowa jest już właściwie standardem - zmienia się natomiast, i to pozytywnie, jej wartość. W licznych wypowiedziach przypominano też niebagatelną rolę bibliotek, często, niestety, niedocenianych przez decydentów. Instytucje te przecież nieodpłatnie udostępniają sieć i jej różnorodne usługi, organizują zasoby cyfrowe, a również przygotowują społeczeństwo do korzystania z technologii. Dynamika rozwoju Internetu, jego nowe funkcje, ale i trudności czy wyzwania powodują, że zasadność tego typu spotkań i wymiany poglądów jest w pełni umotywowana.

Agnieszka Bajor

Instytut Bibliotekoznawstwa i Informacji Naukowej Uniwersytet Sląski w Katowicach

\title{
„Europejska konferencja edukacji informacyjnej” (Dubrownik, Chorwacja, 20-23 października 2014 r.)
}

W dniach 20-23 października 2014 r. w Dubrowniku odbyła się 2. edycja „European Conference on Information Literacy” (ECIL), zorganizowana przez Wydział Nauk o Informacji i Komunikacji Uniwersytetu w Zagrzebiu oraz Wydział Zarządzania Informacją Uniwersytetu Hacettepe w Ankarze. Pomysłodawczyniami ECIL są prof. Serap Kurbanoğlu z Turcji i prof. Sonja Špiranec z Chorwacji.

W konferencji uczestniczyło 248 osób z 48 krajów. Jak podkreślają organizatorzy, określenie „europejski” w nazwie konferencji nie dotyczy miejsc pochodzenia uczestników czy zakresu tematycznego wystąpień, ale lokalizacji geograficznej wydarzenia.

Podczas czterodniowych obrad odbyły się 4 warsztaty, wygłoszono 126 referatów (większość w sesjach równoległych), 14 krótkich prezentacji (tzw. pecha-kucha), zaprezentowano 15 posterów, odbyły się dwie dyskusje panelowe.

Wybrane referaty zostaną opublikowane w recenzowanym tomie pokonferencyjnym, nakładem wydawnictwa Springer w ramach serii „Communications in Computer and Information Science”.

Konferencję rozpoczęła sesja plenarna moderowana przez Serap Kurbanoğlu i Sonję Špiranec.

Pierwszym mówcą był Michael B. Eisenberg, emerytowany profesor z Uniwersytetu Waszyngtona, twórca Big6 Skills - modelu postępowania w zaspokajaniu potrzeb informacyjnych. Jego wystąpienie 
miało bardzo osobisty charakter. Opowiedział o własnych doświadczeniach w rozwijaniu edukacji informacyjnej jako odpowiedzi na wyzwania towarzyszące zmieniającym się technologiom i ich coraz większym udziale w życiu codziennym ludzi. Zainteresowanie decydentów na poziomie lokalnym i krajowym ${ }^{7}$ kompetencjami informacyjnymi jest według niego dowodem na to, że nadszedł właściwy czas dla działaczy edukacji informacyjnej oraz badaczy tego fenomenu (cyt. "This is our time”).

Według Eisenberga edukacja informacyjna polega na ciągłym doskonaleniu określonych umiejętności zapewniających efektywne działanie, oparte na wartościowej informacji. Umiejętności zawarte w modelu są uniwersalną ramą postępowania (procesu informacyjnego).

Inną ramą omawianą podczas ECIL były standardy kompetencji informacyjnych dla szkolnictwa wyższego opracowane przez Association of College \& Research Libraries (ACRL). Pierwszą wersję ogłoszono w 2000 r. Dokument zawierający standardy, wskaźniki i zakładane efekty kształcenia cieszył się przez lata dużym zainteresowaniem bibliotekarzy akademickich, ale miał też swoich antagonistów, głównie wśród badaczy krytykujących dyrektywne podejście do nauczania. Zarzucano mu m.in. brak dopasowania do specyfiki dyscyplin. W 2013 r. ACRL rozpoczęło pracę nad nową wersją standardów, uznając pierwotny dokument za mało aktualny. W 2014 r. ukończono pierwszy etap pracy i udostępniono roboczy dokument do oceny w ramach konsultacji społecznych. Gotowe standardy mają zostać ogłoszone w styczniu $2015 \mathrm{r}^{8}$. Działania ACRL poddawano dyskusji podczas oficjalnych wystąpień, a także w rozmowach kuluarowych.

Nowym standardom poświęcone było wystąpienie kolejnego mówcy w sesji otwierającej - Tefko Saracevica, emerytowanego profesora z Uniwersytetu Stanowego Rutgersa. Poddał on nowe podejście ACRL bardzo surowej ocenie. Uznał, że metoda pracy nad nowymi standardami oraz ich nowy kształt nie jest adekwatny do potrzeb praktyki edukacji informacyjnej. Według Saracevica pierwotne standardy jasno określały zakres umiejętności informacyjnych do opanowania, natomiast nowe dają uczącemu się zbyt dużą swobodę (nazwał to dyskredytująco podejściem „hippie”). W tej krytyce oraz działaniach ACRL upatrywać można zderzenie dwóch podejść do uczenia się kompetencji informacyjnych: dyrektywnego, którego podstawą jest przekonanie o istnieniu zbioru generycznych umiejętności pozwalających na realizację innych aktywności oraz społeczno-kulturowego, w którym kompetencje informacyjne lokuje się w kontekście kulturowym człowieka i jego aktualnych potrzeb.

Ostatni głos w tej sesji należał do Marii-Carme Torras i Calvo (Biblioteka Wyższej Szkoły w Bergen), która przedstawiła ogłoszoną podczas tegorocznego (2014) Światowego Kongresu IFLA Deklarację Liońską (Stowarzyszenie Bibliotekarzy Polskich jest sygnatariuszem deklaracji), traktującą kompetencje informacyjne jako warunek zapewnienia zrównoważonego rozwoju: „access to information, and the skills to use it effectively, are required for sustainable development" (Lyon Declaration', 2014). Deklaracja wpisuje się w ramy współdziałania dla rozwoju po 2015 r. (oparte na prawach człowieka), ustanowione przez Organizację Narodów Zjednoczonych.

Referaty w kolejnych sesjach zostały podzielone na dwanaście bloków tematycznych:

- Information literacy and other literacies,

- Information literacy and democracy,

- Information literacy in theoretical context,

- Information literacy assessment,

- Information literacy and libraries,

- Information literacy research,

- Information literacy and lifelong learning,

7 M. Eisenberg odwołał się m.in. do decyzji prezydenta Stanów Zjednoczonych Baracka Obamy o ustanowieniu października 2009 r. miesiącem edukacji informacyjnej.

${ }^{8}$ Bieżące prace zespołu ACRL można śledzić na stronie internetowej: http://acrl.ala.org/ilstandards/

${ }^{9}$ Lyon Declaration on Access to Information and Development (2014). Pobrane z: http://www.lyondeclaration.org 
- Information literacy policies,

- Information literacy instruction,

- Information literacy education,

- Best practice,

- Doctoral forum.

Edukacja i kompetencje informacyjne były omawiane podczas ECIL na wielu płaszczyznach, z szerokiej perspektywy, ukazującej jak information literacy wiąże się z innymi zjawiskami edukacyjnymi, społecznymi i ekonomicznymi, takimi jak: kompetencje cyfrowe, wizualne, medialne, informacja zdrowotna, zachowania informacyjne, trans-kompetencje. Edukacja informacyjna była rozpatrywana w odniesieniu do społeczeństwa informacyjnego, cyfrowego i multimedialnego, gospodarki wiedzy, czy szerzej - do XXI wieku. Organizatorzy zadbali o to, aby na konferencji wybrzmiały różne głosy i obecne były odmienne podejścia badawcze. Było to niewątpliwym atutem ECIL. Oprócz wspomnianego już podejścia dyrektywnego oraz społeczno-kulturowego do uczenia się kompetencji informacyjnych, słychać było również głos zwolenników transformatywnego (w tym krytycznego) uczenia się.

W sprawozdaniu omówione zostały jedynie te referaty, których wysłuchały sprawozdające. Szczegółowy program konferencji, abstrakty oraz slajdy ilustrujące referaty dostępne są na stronie ECIL 2014, http://ecil2014.ilconf.org/. Obszerną relację z wybranych sesji odnaleźć można również na blogu Sheili Webber z Uniwersytetu w Sheffield: http://information-literacy.blogspot.com/search/ label/ecil2014.

Kilkunastu referentów zajęło się teoretycznym ujęciem information literacy. David Bawden z City University w Londynie podjął się analizy koncepcji i modeli pobocznych w stosunku do information literacy. Jako że nadrzędnym celem jest kształcenie kompetencji informacyjnych, aby pomóc ludziom w zostaniu samowystarczalnymi i samodzielnymi użytkownikami informacji, Bawden zaproponował koncepcję biegłości informacyjnej (ang. information fluency) jako środka promocji edukacji informacyjnej dostosowanej do indywidualnych, zróżnicowanych potrzeb użytkowników w zmieniającym się środowisku informacyjnym.

Louise Limberg ze Szwedzkiej Szkoły Bibliotekoznawstwa i Informacji Naukowej w Borås przeanalizowała edukację informacyjną postrzeganą jako dyscyplinę nauki funkcjonującą odrębnie lub na styku informacji naukowej oraz pedagogiki. Dostarczyła argumentów na każdą z postulowanych klasyfikacji. Jednak swój referat skonkludowała stwierdzeniem, że środowiska biblioteczne i naukowe zamiast zajmować się samym terminem, powinny bardziej skupić się na badaniach teoretycznych i empirycznych w dziedzinie information literacy.

Andrew Whitworth z Uniwersytetu w Manchesterze przedstawił koncepcję radical information literacy, której korzenie tkwią w pedagogice emancypacyjnej. Withworth zauważył, że dyskurs wokół kompetencji informacyjnych został zawłaszczony przez zinstytucjonalizowane myślenie o edukacji informacyjnej jako praktyce bibliotecznej. Skutkiem tego jest brak przestrzeni dla innych poszukiwań, pogłębionej refleksji teoretycznej nad fenomenem kompetencji informacyjnych oraz nad samą praktyką. Odnosząc się do Freirowskiego rozumienia edukacji jako procesu zmiany, postulował włączenie w myślenie o edukacji informacyjnej kategorii transformacji. Nawiązał jednocześnie do koncepcji, ujawnianej najszerzej w pracach Annemaree Lloyd, traktowania information literacy jako praktyki społecznej. Radykalna edukacja informacyjna, proponowana przez Withwortha, odrzuca standardy jako uniwersalną ramę uczenia się, jest kontekstualna, zanurzona w społeczno-kulturowym otoczeniu uczącego się, korzysta z praktyk demokratycznych, odwraca myślenie o uczeniu się $\mathrm{z}$ „uczenia się do" na „uczenie się w”.

Sheila Webber z Uniwersytetu w Sheffield i Bill Johnston, z Uniwersytetu Strathclyde w Glasgow w swoim wystąpieniu powrócili do głośnego artykułu z 2006 r., w którym przedstawili information literacy jako odrębną dyscyplinę naukową. Po ośmiu latach ponownie przeprowadzili podobną analizę i w jej świetle uznali, że wzmocnił się status tej dyscypliny naukowej, zwłaszcza w świetle prowadzonych 
przez ACRL prac nad zaktualizowaniem standardów information literacy dla szkolnictwa wyższego, w których wykorzystano koncepcje wartości progowych. Takie wartości muszą być wpisane w obręb określonej dyscypliny. ACRL jest więc jedną z organizacji, która legitymizuje status information literacy.

Katarzyna Materska z Uniwersytetu Kardynała Stefana Wyszyńskiego w Warszawie podjęła temat heurystyki rozumianej jako aktywność pomagająca użytkownikom informacji we właściwymi dobieraniu źródeł i podejmowaniu decyzji co do ich wykorzystania. Referentka omówiła także heurystykę w kontekście programów z zakresu edukacji informacyjnej.

Dla praktyków interesujące były także wystąpienia prezentujące przykłady konkretnych wdrożeń programów z zakresu edukacji informacyjnej.

Kristina Hintikka i Ann-Louise Paasio z Biblioteki Uniwersytetu w Turku zaprezentowały kurs dla doktorantów pn. „Zasoby informacyjne i narzędzia badawcze”, prowadzony po fińsku i angielsku. Kurs poświęcony jest bazom danych i narzędziom do zarządzania bibliografią oraz procesowi publikowania naukowego. Prowadzi go siedmiu bibliotekarzy dla małych grup studentów reprezentujących różne dyscypliny nauki. Składa się z pięciu sesji, jest nagradzany jednym punktem ECTS.

Ane Landøy z Uniwersytetu w Bergen, Natalia Cheradi z Akademii Nauk Ekonomicznych w Mołdawii i Angela Repanovici z Uniwersytetu Transylwańskiego w Braşov przedstawiły wyniki badań porównawczych potrzeb informacyjnych doktorantów mołdawskich i norweskich. Postulowały zdefiniowanie roli biblioteki w procesie badawczym prowadzonym przez doktorantów oraz wprowadzenie obowiązkowych szkoleń dla tej grupy użytkowników.

Philip Russel z Instytutu Technologicznego Tallaght w Dublinie przybliżył możliwości zastosowania otwartych zasobów edukacyjnych w szkoleniach podnoszących kompetencje informacyjne. Szkolenia e-learningowe oferowane przez jego uczelnię, dzięki wzbogaceniu o te zasoby, zwiększyły swoją wartość i zaczęły być chętniej wykorzystywane.

Referaty traktujące o użytkownikach informacji objęły łącznie wszystkie grupy wiekowe.

John Gathegi z Uniwersytetu Południowej Florydy w Tampa zajął się zagadnieniem edukacji medialnej, uwypuklając media społeczne i zjawisko dzielenia się treściami w sieci. Podkreślił wagę edukacji medialnej i zasadność jej wprowadzenia od najmłodszych lat.

Młodszym grupom użytkowników informacji poświęcone było także wystąpienie Ewy Rozkosz z Dolnośląskiej Szkoły Wyższej we Wrocławiu. Referentka omówiła wyniki badań realizowanych w dwóch projektach „Dzieci Sieci: kompetencje komunikacyjne najmłodszych” oraz „Dzieci Sieci 2.0: kompetencje komunikacyjne młodych".

Podczas ECIL2014 zwracano też uwagę na pomijanie w polityce na różnych szczeblach tematyki edukacji informacyjnej, kompetencji informacyjnych oraz zagadnień pokrewnych.

Carla Basili z Instytutu Ceris w Rzymie i Stéphane Goldstein z Research Information Network $\mathrm{w}$ Londynie poruszyli kwestie dotyczące naukowej edukacji informacyjnej (ang. scientific information literacy) - zagadnienia pomijanego w dokumentach publikowanych w ramach programu Europejska Przestrzeń Badawcza. Innymi słowy, zakłada się, że wiedza oraz umiejętności związane z posługiwaniem się informacją o charakterze naukowym są niejako nabywane w toku pracy badawczej i nie ma potrzeby poświęcania im szczególnej uwagi. Jest to sprzeczne z założeniami przyjętymi w dokumentach unijnych dotyczących otwartego dostępu (ang. Open Access) i poprawienia dostępu do informacji naukowej. Autorzy przekonywali, że realizacja takich założeń wymaga przygotowania oferty edukacji informacyjnej skierowanej do naukowców i innych osób zajmujących się obsługą badań.

Kwestię pomijania zagadnień dotyczących bibliotek i kompetencji informacyjnych podjęła także Zuza Wiorogórska z Biblioteki Uniwersyteckiej w Warszawie w referacie poświęconym zadaniom bibliotek w kształceniu kompetencji XXI wieku. Zwróciła ona uwagę na ignorowanie lub umniejszanie dydaktycznej roli bibliotek w Polsce, zarówno w dokumentach rządowych, jak i statutach uczelni wyższych.

Ivana Hebrang Grgić z Uniwersytetu w Zagrzebiu poruszyła kwestię etyki w komunikacji naukowej. Przekonywała, że szkolenia z zakresu edukacji informacyjnej mogą mieć duży wpływ na 
dobrze prowadzone badania, odpowiednie cytowanie źródeł, a co za tym idzie, unikanie plagiatów. Referentka przeanalizowała wskazówki dla autorów w 112 czasopismach naukowych z dziedziny nauk społecznych. Okazało się, że w wielu z nich jest mowa jedynie o stylach cytowania, nie ma jednak wzmianki o autorstwie, plagiacie czy etyce.

Sabina Cisek z Uniwersytetu Jagiellońskiego przybliżyła metody jakościowe wykorzystywane w badaniach edukacji informacyjnej. Na podstawie analizy abstraktów i pełnych tekstów 103 publikacji z lat 2011-2014, dostępnych w bazie LISTA ustaliła, że najczęściej wykorzystywanymi technikami badawczymi są wywiady indywidualne i focusowe.

ECIL to forum obecnie najlepiej służące wymianie doświadczeń z prac naukowych i prac bibliotecznych prowadzonych na polu edukacji informacyjnej. Zdecydowanie zasługuje na uwagę wszystkich zainteresowanych tą tematyką. Jest to konferencja odznaczająca się wysokim poziomem merytorycznym i organizacyjnym. Uczestnikom zapewniono doskonałe warunki nie tylko do dzielenia się wynikami prac, ale też do spotkań nieformalnych, będących przecież równie ważnym aspektem konferencji. ECIL to już marka. Duże zainteresowanie konferencją to dowód, że takie forum wymiany doświadczeń było w Europie bardzo potrzebne.

Polskę na ECIL 2014 reprezentowały: Sabina Cisek (UJ), Katarzyna Materska (UKSW), Ewa Rozkosz (DSW) i Zuza Wiorogórska (UW).

ECIL 2015 odbędzie się w dniach 19-22 października 2015 r. w stolicy Estonii.

Ewa Rozkosz

Dolnośląska Szkoła Wyższa

Zuza Wiorogórska

Biblioteka Uniwersytecka $w$ Warszawie

Nadestano: 19.11.2014. 